\title{
Markers of Oxidative Stress in the Exhaled Breath Condensate of Workers Handling Nanocomposites
}

\author{
Daniela Pelclova $^{1, *(\mathbb{D}), \text { Vladimir Zdimal }}{ }^{2}$ (D), Jaroslav Schwarz ${ }^{2}$, Stepanka Dvorackova ${ }^{3}$, \\ Martin Komarc ${ }^{4,5}$, Jakub Ondracek ${ }^{2}$, Martin Kostejn ${ }^{2}$ (D), Petr Kacer ${ }^{6}$, Stepanka Vlckova ${ }^{1}$, \\ Zdenka Fenclova $^{1}$, Alexey Popov ${ }^{3}$, Lucie Lischkova ${ }^{1}$, Sergey Zakharov ${ }^{1}$ and Dhimiter Bello ${ }^{7}$ \\ 1 Department of Occupational Medicine, First Faculty of Medicine, Charles University in Prague and General \\ University Hospital in Prague, Na Bojisti 1, 12800 Prague 2, Czech Republic; Stepanka.Vlckova@vfn.cz (S.V.); \\ zdenka.fenclova@lf1.cuni.cz (Z.F.); Lucie.Lischkova@vfn.cz (L.L.); Sergej.Zacharov@vfn.cz (S.Z.) \\ 2 Institute of Chemical Process Fundamentals of the CAS, Rozvojová 1/135, 16502 Prague 6, Czech Republic; \\ zdimal@icpf.cas.cz (V.Z.); schwarz@icpf.cas.cz (J.S.); ondracek@icpf.cas.cz (J.O.); kostejn@icpf.cas.cz (M.K.) \\ 3 Department of Machining and Assembly, Department of Engineering Technology, Department of Material \\ Science, Faculty of Mechanical Engineering, Technical University in Liberec, Faculty of Mechanical \\ Engineering, Studentská 1402/2, 46117 Liberec, Czech Republic; stepanka.dvorackova@tul.cz (S.D.); \\ alespopov@yandex.ru (A.P.) \\ 4 Institute of Biophysics and Informatics, First Faculty of Medicine, Charles University in Prague and General \\ University Hospital in Prague, Salmovská 1, 12000 Prague 2, Czech Republic; martin.komarc@lf1.cuni.cz \\ 5 Faculty of Physical Education and Sport, First Faculty of Medicine, Charles University in Prague and \\ General University Hospital in Prague, José Martího 31, 16252 Prague 6, Czech Republic \\ 6 Biocev, 1st Faculty of Medicine, Charles University, Prumyslova 595, 25250 Vestec, Czech Republic; \\ petr.kacer69@gmail.com \\ 7 Department of Biomedical and Nutritional Sciences, Zuckerberg College of Health Sciences, \\ Lowell, MA 01854, USA; Dhimiter_Bello@uml.edu \\ * Correspondence: daniela@pelclova.cz; Tel.: +420-224-964-532
}

Received: 17 July 2018; Accepted: 8 August 2018; Published: 10 August 2018 updates

\begin{abstract}
Researchers in nanocomposite processing may inhale a variety of chemical agents, including nanoparticles. This study investigated airway oxidative stress status in the exhaled breath condensate (EBC). Nineteen employees $(42.4 \pm 11.4 \mathrm{y} / \mathrm{o})$, working in nanocomposites research for $18.0 \pm 10.3$ years were examined pre-shift and post-shift on a random workday, together with nineteen controls ( $45.5 \pm 11.7 \mathrm{y} / \mathrm{o})$. Panels of oxidative stress biomarkers derived from lipids, nucleic acids, and proteins were analyzed in the EBC. Aerosol exposures were monitored during three major nanoparticle generation operations: smelting and welding (workshop 1) and nanocomposite machining (workshop 2) using a suite of real-time and integrated instruments. Mass concentrations during these operations were $0.120,1.840$, and $0.804 \mathrm{mg} / \mathrm{m}^{3}$, respectively. Median particle number concentrations were $4.8 \times 10^{4}, 1.3 \times 10^{5}$, and $5.4 \times 10^{5}$ particles $/ \mathrm{cm}^{3}$, respectively. Nanoparticles accounted for 95, 40, and 61\%, respectively, with prevailing Fe and Mn. All markers of nucleic acid and protein oxidation, malondialdehyde, and aldehydes $\mathrm{C}_{6}-\mathrm{C}_{13}$ were elevated, already in the pre-shift samples relative to controls in both workshops. Significant post-shift elevations were documented in lipid oxidation markers. Significant associations were found between working in nanocomposite synthesis and EBC biomarkers. More research is needed to understand the contribution of nanoparticles from nanocomposite processing in inducing oxidative stress, relative to other co-exposures generated during welding, smelting, and secondary oxidation processes, in these workshops.
\end{abstract}

Keywords: nanoparticles; workers; nanocomposites; inhalation; exhaled breath condensate; oxidative stress; occupational exposure 


\section{Introduction}

The global market for nanocomposites is expected to reach over $\$ 5$ billion by 2020 , and it is fueled by demand in numerous sectors, from automotive to military and aerospace applications [1]. Research and development in nanocomposite synthesis and processing proceed larger scale commercialization. Literally thousands of laboratories in academia and private industrial sector engage in nanocomposite research and development by experimenting with a variety of nanofillers and polymer types. Interest in understanding exposures to engineered nanomaterials used as fillers in nanocomposite synthesis, as well as incidental nanoparticle and carbon nanotube (CNT) exposure during nanocomposite synthesis and post-processing can be traced as far back as a decade ago [1,2]. Several recent studies have focused on end-of-life grinding and recycling of CNT-composites [3,4]. In contrast to numerous studies on exposures, little information is available on the health effects of workers and researchers engaged in nanocomposite research and development or manufacturing [5-8]. Polycyclic aromatic hydrocarbons (PAHs) are chemicals reactive towards a number of atmospheric oxidants. It should be noted that these environments are often characterized by mixed exposures (vapor and aerosols phases and mixed chemistry). Although the focus is on nanoparticles, other co-exposures may play an important role in the health effect.

Volatile organic compounds (VOCs) and semi-volatile organic compounds (SVOCs), generated as a result of polymer heating and thermal degradation, polycyclic aromatic hydrocarbons (PAHs), and other byproducts of chemical reactions with ozone and catalytic metal oxides used as fillers, may lead to complex airborne pollutants. Lower molecular weight PAH vapor may be converted to higher molecular weight PAHs and other compounds via catalytic reactions with metal oxide fillers [9]. Condensation of organic matter on metal oxides nanoparticles may also enhance their transport in deep airways. Exposures to welding fumes that may take place alongside nanocomposite manufacturing include multiple transition metal species, especially redox active $\mathrm{Zn}$ and Mn species, both soluble and insoluble, and that exposures to Mn species vary with specific processes and shield gases [10]. Background ozone, as well as that produced by certain processes, such as welding, play an important role on secondary aerosol formation via oxidation reactions. Ozone is also a strong oxidant on its own right. With regards to ozone, the maximum allowable daily 8-h concentrations are not commonly exceeded [11]. The estimated percentage of the nanofraction of Mn deposited in a mild steel-welder's respiratory system ranged between 10 and 56\% [12]. For stainless steel welding, the nanoparticle respiratory deposition samplers collected $59 \%$ of the total $\mathrm{Mn}, 90 \%$ of the total $\mathrm{Cr}$, and $64 \%$ of the total $\mathrm{Ni}$. These results indicate that most of the $\mathrm{Cr}$ and more than half of the $\mathrm{Ni}$ and $\mathrm{Mn}$ in the fumes were in the fraction smaller than $300 \mathrm{~nm}$ [12]. Although our focus is on the lesser-studied exposures to nanoparticles, it is important to recognize that exposures at the nanocomposite synthesis and processing sites may be chemically more complex and less understood.

Since inhalation remains the major exposure pathway to nanoparticles during nanocomposite manufacturing, the respiratory system is the main portal of entry and the primary target organ of concern. However, there are only a few sensitive non-invasive methods to probe deep airways in humans. Exhaled breath condensate (EBC) collection and analysis is one such technique. EBC is a liquid that reflects the composition of the fluid lining the airway [13]. It is obtained non-invasively from subjects after cooling of the exhaled air. EBC is composed mainly of water (99.9\%) and a small proportion of water-soluble and insoluble compounds. These non-volatile compounds can include small inorganic ions, large organic molecules (urea, organic acids, amino acids), proteins, and macromolecules that presumably originate from the airway-lining fluid in the form of aerosolized particles formed during the reopening of distal airways [14]. Analysis of EBC enables measurement of biomarkers present in the deep airways.

A large body of in vivo and in vitro particle toxicology and nanotoxicology studies have shown that nanoparticles induce toxicity via a number of mechanisms, including intracellular reactive oxygen species (ROS) generation and ensuing oxidative stress, $\mathrm{Ca}^{2+}$ flux, induction of pro-inflammatory mediators through receptor stimulation, hypersensitivity, genotoxicity, and cell necrosis [15-18]. 
The homeostatic redox state of the host becomes disrupted upon ROS induction by nanoparticles. These sequential molecular and cellular events are known to cause oxidative stress, followed by severe cellular genotoxicity and then programmed cell death. Both experimental and epidemiological studies have indicated that chronic inflammation is involved in and plays a critical role in several chronic diseases, including respiratory and cardiovascular diseases, and lung tumorigenesis [17,19-21]. However, there is no evidence that particles below $100 \mathrm{~nm}$ show any step-change in their hazard meaning that there is no evidence of any novel "nano-specific hazard". Therefore, conventional particle toxicology data are useful and relevant to the determination of the nanoparticle hazard [22].

A common feature of many aerosols in the workplaces is their ability to generate ROS, which induce oxidative damage to biomolecules, leading to activation of redox signaling pathways. 8-iso-Prostaglandin F2 $\alpha$ (8-isoprostane) is produced by free-radical lipid peroxidation of arachidonic acid, and represents an in vivo specific marker of oxidative stress. Oxidative modification of lipids occurs in vivo during aging and in certain disease conditions. Lipid peroxides are unstable indicators of oxidative stress in cells that form more complex and reactive compounds, such as malondialdehyde (MDA), 4-hydroxy-trans-hexenal (HHE), and 4-hydroxy-trans-nonenal (HNE), that can form covalent adducts with biomolecules including DNA and proteins, and thus, are regarded as genotoxic and cytotoxic [23]. 3-Nitrotyrosine (3-NOTyr) and 3-chlorotyrosine (3-ClTyr) are stable products of peroxynitrite $\left(\mathrm{ONOO}^{-}\right)$and hypochlorous acid $(\mathrm{HClO})$, respectively, with tyrosine residues of proteins, which may lead to functional relationship with the neutrophilic inflammation. Both 3-NOTyr and $o$-tyrosine (o-Tyr) have been found in patients with interstitial lung diseases, but studies on other biomarkers are limited. Oxidative damage to nucleic acids may be measured using 8-hydroxy-2-deoxyguanosine (8-OHdG) and 8-hydroxyguanosine (8-OHG) formed by oxidation of guanine from DNA and 5-hydroxymethyl uracil (5-OHMeU) from RNA [16,23].

The first aim of this study was to characterize workplace aerosols generated during synthesis and post-processing of nanocomposites, and associated operations, including machining of nanocomposite materials, smelting, and welding. Another aim was to measure markers of oxidative stress in the EBC of workers exposed to nanoparticles and to study their possible association with workplace environments. This is the first study to report on the respiratory health status on this cohort of researchers and applicators, using a suite of well-established biomolecular markers measured in the EBC. In a separate paper, we report on inflammatory leukotrienes (B4 and cysteinyl leukotrienes), pro-inflammatory cytokines and chemokines, such as tumor necrosis factor (TNF), interleukins (IL 5, IL 9), and their anti-inflammatory counterparts (lipoxins; IL 4, and IL 10), in the EBC of workers, as well as fractional exhaled NO, and lung function using spirometry [24].

\section{Materials and Methods}

\subsection{Facility and Operations Description}

The research and development unit at a national research university is trying to develop a new thermoplastic or reactoplastic (thermoset) composite material that exhibits comparable performance characteristics with steel, with regard to its low thermal expansion, hardness, and resistance to surface scratching. This new nanocomposite material is intended for use in automated measuring devices of plastic materials, where metal instruments cannot be used because of measurement errors related to their higher expansion and the risk of scratching the surface of plastics.

Researchers would normally perform three different operations: welding on metal surfaces, smelting of mixtures containing nanoadditives, and machining of the finished nanocomposite. The researchers were divided into two separate groups in two workshops. Welding and smelting took place together in workshop 1, located in the basement of the building, whereas composite machining took place in a second workshop located on the ground floor of the same building. Researchers would usually carry on their daily operations in the workshops for about $2 \mathrm{~h}$, with the majority of the working 
day spent in their offices. The three operations would occur simultaneously in both workshops, and be performed by different individuals.

On the day of examination, the duration of each of these (simultaneous) operations lasted about $150 \mathrm{~min}$, and the original source of a nanocomponent was amorphous colloidal nanoSiO in epoxide resins.

Welding on metal surfaces (workshop 1) was conducted on mild steel S355J2 using metal active gas (MAG) technology with $\mathrm{Ar} / \mathrm{CO}_{2}$ mixed-copper coated wire (G3Si) and coated electrodes EB 121 (content in wt \%: C 0.05, Si 0.4, Mn 0.8). The S355J2 steel content was (in wt \%): Fe, 97.39; C, 0.24; $\mathrm{Mn}, 1.70 ; \mathrm{Si}, 0.6 ; \mathrm{P}, 0.035 ; \mathrm{S}, 0.035$ ). Also in workshop 1 , an $\mathrm{AlSi}_{9} \mathrm{Cu}_{3}$ alloy (content in wt \%: $\mathrm{Al}, 83.50$; $\mathrm{Si}, 10.0 ; \mathrm{Fe}, 0.8 ; \mathrm{Cu}, 3.0 ; \mathrm{Mn}, 0.55 ; \mathrm{Mg}, 0.25 ; \mathrm{Cr}, 0.15 ; \mathrm{Ni}, 0.55 ; \mathrm{Zn}, 1.2)$, mixed with modifying salts $(\mathrm{NaCl}, \mathrm{KCl}, \mathrm{NaF})$, was smelted in the smelting oven at $760^{\circ} \mathrm{C}$, in a mold made of sand mixed with a bentonite filler.

Machining of surfaces of previously finished nanocomposite blocks, including milling, grinding, and polishing, was performed in workshop 2. Mixing of the fillers with matrices to prepare nanocomposites samples was performed about twice per month, and lasted about $2 \mathrm{~h}$.

On the day of examination, five nanocomposite specimens were processed on workshop 2. Two samples contained epoxide resins with $\mathrm{SiO}_{2}$ fillers. One nanocomposite specimen contained $1.0 \%$ $w / w$ amorphous colloidal nanoSiO ${ }_{2}$, whereas the second specimen contained crushed rice husks with $50 \%$ cellulose, $30 \%$ lignin, and up to $20.0 \% \mathrm{SiO}_{2}$ as fillers. Three additional samples were geopolymers, first containing metakaolin mixed with $\mathrm{NaOH}$ only, and two others were filled with ash or basalt, each at $40 \% w / w$. The formulations of nanocomposites differed over time, according to research aims. On other days, the operations may include thermoplast melting (polypropylene) and mixing with milled coconut fibers, composite materials production, or adding textile fibers, glass, etc.

\subsection{Subjects}

EBC samples were collected from the 19 nanocomposite-synthesizing and processing researchers (14 men, 5 women, all non-smokers) in September 2016. On the day of examination, eleven researchers were working in workshop 1 (welding and smelting), and seven in workshop 2 (machining of nanocomposites). The control group was composed of 19 subjects (13 men, 6 women, all non-smokers) from the same town, not employed in this plant nor occupationally exposed to dust or other health risks.

Exposed and control subjects were administered a standardized questionnaire that collected information on personal and occupational history, medical treatments, dietary habits, smoking habits, and alcohol intake. Participants underwent a physical examination in another part of the building, followed by the collection of their EBC. Exclusion criteria for all subjects were history of tuberculosis, myocarditis, congenital heart disease, lung cancer, and recent fever and/or common cold symptoms. Nanocomposite researchers provided EBC both pre-shift (i.e., before $2.5 \mathrm{~h}$ exposure to aerosol in the workshops) and post-shift (i.e., after aerosol exposure in the workshop). For simplicity, we refer to these examinations as pre-shift and post-shift, even though the remainder of their total 8-h shift was spent in their offices. Among the workers, seven were working in the same workshop as usual, and the remaining twelve were working in both workshops during the previous weeks. The controls provided EBC only once at approximately the same time of day as researchers in the workshop floor. The pre-shift samples were used to study the subacute/chronic effect on the subjects resulting from exposures in previous days. Comparison of the pre-shift and post-shift samples was intended to evaluate the acute effect of exposure during the shift.

The study was conducted according to the Declaration of Helsinki. The Ethical Committee of the 1st Medical Faculty, Charles University, approved the study. All participants were informed of the study aim at least five days earlier, and signed an informed consent form before the study began. 


\subsection{Workplace Aerosol Measurements}

Chemical and physical characterization of nanoparticles and aerosols was carried out using a set of real-time and size selective aerosol instruments. A Berner low-pressure impactor (BLPI, HAUKE $\mathrm{GmbH}$, Gmunden, Austria) [25,26] was used to sample aerosol particles onto 10 stages corresponding to their aerodynamic diameter, covering the $25 \mathrm{~nm}-13.6 \mu \mathrm{m}$ size range. The impactor samples were analyzed gravimetrically on an M5P balance (Sartorius $\mathrm{GmbH}$, Goettingen, Germany, $1 \mu \mathrm{g}$ resolution), followed by ion chromatography (IC) in a Dionex 5000 (Dionex Co., Sunnyvale, CA, USA), whose two-channel system enabled parallel determination of water soluble ions (both anions and cations) as described by Talbot et al. [27]. The impactors were placed about $3 \mathrm{~m}$ from the individual processes at a height of approximately $1.5 \mathrm{~m}$.

The online real-time instrumentation included two standard aerosol spectrometers-a scanning mobility particle sizer SMPS 3936L (TSI Inc., Shoreview, MN, USA) and an aerodynamic particle sizer APS 3321 (TSI Inc., Shoreview, MN, USA), covering the size range of aerosol particles from $6 \mathrm{~nm}$ up to $20 \mu \mathrm{m}$. In addition, an ultrafine condensation particle counter UCPC 3025 (TSI Inc., Shoreview, MN, USA) was used to measure the total particle number concentration $(10 \mathrm{~nm}-\sim 1 \mu \mathrm{m})$ and three optical particle sizers OPS 3330 (TSI Inc., Shoreview, MN, USA) measuring number size distribution in the range $300 \mathrm{~nm}-10 \mu \mathrm{m}$. All instruments sampled for the whole duration of the current nanoparticle generation operations (welding, soldering, synthesis, nanocomposite machining). Background nanoparticle concentration was monitored before the operations started. The online instruments were placed about $1.5 \mathrm{~m}$ from the workers at a height of approximately $1.5 \mathrm{~m}$. The details concerning the samples collected are shown in Supplementary Table S1.

A scanning electron microscope (SEM) Indusem, (TESCAN ORSAY HOLDING a.s., Brno, Czech Republic), equipped with energy-dispersive X-ray (EDX) spectroscopy (XFlash detector 5010, Bruker, Karlsruhe, Germany), was used for elemental analyses and EDX spectra acquisition at an accelerating voltage of $15 \mathrm{kV}$ for $120 \mathrm{~s}$. Carbon sputtering was used for deposition of a conducting layer (ca. $15 \mathrm{~nm}$ thick) onto the samples, to prevent charging. To cover a representative area and minimize the effects of possible heterogeneities, seven square areas containing aerosol with an edge length of $200 \mu \mathrm{m}$ were scanned on each sample. Carbon, oxygen, and copper were excluded from the results as they were present in the substrates, superficial conducting layer, and supporting material.

The data from EDX were recalculated to mass concentration using sulfur as internal reference, and sulfate mass concentration from IC recalculated to sulfur under the assumption that all sulfur in the sample was present as sulfates. Control recalculations were done using chlorine as reference and chloride mass concentration from IC, with very similar results as for sulfur.

\subsection{Collection and Analysis of Oxidative Stress Markers in EBC}

EBC samples were collected using an Ecoscreen Turbo DECCS device (Jaeger, Hochberg, Germany), that was equipped with a filter. All subjects breathed tidally through a mouthpiece connected to the condenser $\left(-20^{\circ} \mathrm{C}\right)$ while wearing a nose-clip. A minimum volume of exhaled air of $120 \mathrm{~L}$ was maintained (monitored via the EcoVent device by Jaeger, Wurzburg, Germany), and the time of collection was about $15 \mathrm{~min}$ [9]. All samples were immediately frozen and stored at $-80{ }^{\circ} \mathrm{C}$.

A panel of oxidative stress markers derived from free radical oxidation of polyunsaturated fatty acids, nucleic acid bases, and proteins was analyzed after solid-phase extraction (SPE) by liquid chromatography-electrospray ionization-tandem mass spectrometry (LC-ESI-MS/MS) using deuterium-labelled internal standards, as previously described [28-30]. These biomarkers included lipid oxidation-MDA, $\mathrm{HHE}, \mathrm{HNE}$, aldehydes $\mathrm{C}_{6}-\mathrm{C}_{13}$, and 8-isoprostane; nucleic acids-8-OHG, 8-OHdG, and 5-OHMeU; and protein-o-Tyr, 3-ClTyr, and 3-NOTyr. The $\alpha$-amylase concentration was monitored [13] to account for any sample contamination by saliva [31]. Electrical conductivity of EBC was measured as a reference indicator in EBC dilution to account for changes in respiratory solute concentration [32]. All samples were blinded to personnel involved. 


\subsection{Environmental Contamination}

Air concentrations of $\mathrm{SO}_{2}, \mathrm{O}_{3}$, nitrogen oxides $\left(\mathrm{NO}_{x}\right)$, particulate matter $(\mathrm{PM})_{2.5}$ and $\mathrm{PM}_{10}$, recorded on an hourly basis, were taken from the monitoring data on the same days when the workers were examined. Air concentrations were obtained from the National Hydrometeorological monitoring system at the closest stationary monitoring station. The distance to the site of EBC collection was about $3.0 \mathrm{~km}$. Environmental monitoring employed the following analytical methods: UV-fluorescence $\left(\mathrm{SO}_{2}\right)$, chemiluminescence $\left(\mathrm{NO}_{x}\right)$, UV-absorption $\left(\mathrm{O}_{3}\right)$, and an optoelectronic method (PM).

\subsection{Statistical Analysis}

Basic descriptive statistics (mean, median, confidence interval, standard deviation, skewness, and kurtosis) were computed for all variables, which were subsequently tested for normality using the Kolmogorov-Smirnov test. The chi-square test was used to compare frequency counts of demographic categorical variables (alcohol consumption) in groups of workers vs. controls. Differences in interval variables were tested using independent-group t-test (for normally distributed variables) and the Mann-Whitney $U$ test (for non-normally distributed variables, such as markers of oxidative stress in EBC). The paired sample $t$ test (or the Wilcoxon signed-rank test as a nonparametric alternative) was used to compare workers' pre-shift and post-shift values of oxidative stress markers. The bivariate relationship between variables under study was assessed using the Spearman correlation coefficient. Multiple regression analysis was used to predict markers in EBC by a set of predictors (nanoparticle exposure-yes/no, age, sex, alcohol consumption-yes/no, body mass index-BMI). Statistical significance was set at $p<0.05$. All analyses were conducted using SPSS version 22.0 (SPSS, Inc., Chicago, IL, USA).

\section{Results}

\subsection{Subjects}

Demographic characteristics of the exposed and control groups are presented in Table 1. There were no differences in age, gender, body mass index, and alcohol consumption in the two groups studied (all $p>0.05)$.

Table 1. Characteristics of the groups of subjects.

\begin{tabular}{ccc}
\hline Subjects & Exposed & Controls \\
\hline Number of Subjects & $\mathbf{1 9}$ & $\mathbf{1 9}$ \\
\hline Age (years) & $42.4 \pm 11.4$ & $45.4 \pm 11.7$ \\
Body Mass Index $\left(\mathbf{k g} / \mathbf{m}^{\mathbf{2}}\right)$ & $27.69 \pm 6.30$ & $24.39 \pm 4.04$ \\
Alcohol occasionally $(\boldsymbol{n}, \mathbf{\%})$ & $17(90 \%)$ & $16(84 \%)$ \\
Employment in nanocomposite production (years) & Mean $18.0 \pm 10.3$ & - \\
\hline
\end{tabular}

Personal protective equipment was used for welding (welding helmets, leather gloves and leather aprons) and smelting (gloves). No respiratory protection was used during any of the operations.

\subsection{Workplace Aerosol Results}

\subsubsection{Number Size Distributions}

Metal Active Gas (MAG) Welding

MAG welding resulted in monomodal particle size distribution, with particles mainly in the accumulation size range, with modal size around $200 \mathrm{~nm}$. Total median particle number concentration was $1.3 \times 10^{5}$ particles $/ \mathrm{cm}^{3}$ (the interquartile range (IQR) was from $1.2 \times 10^{5}$ to $1.5 \times 10^{5}$ particles $/ \mathrm{cm}^{3}$ ) and maximum number concentration reached about $2.1 \times 10^{5}$ particles $/ \mathrm{cm}^{3}$. However, these particles were formed by coagulation of primary particles smaller than $10 \mathrm{~nm}$ with high concentrations, 
as was observed from the time evolution of number concentrations and size distributions. While concentrations of the lowest size bins were quickly decreasing, concentrations of accumulation mode particles steadily increased.

Smelting

Particle size distributions produced by smelting were multimodal. The first mode, $<25 \mathrm{~nm}$, was formed by the primary nanoparticles originating from evaporation of the material being smelted and its subsequent condensation. The second mode, around $50 \mathrm{~nm}$, was a product of coagulation of the primary particles. The third mode, with maxima around $200 \mathrm{~nm}$, was most probably coming from the previous operation, MAG welding, where the particles in the workplace did not have enough time to deposit. Most of the particles produced by smelting were released when the smelting oven was open. The measurement after the smelting was finished showed a change of the size distribution shape into unimodal, and the shift of the mode of primary particles to about $25 \mathrm{~nm}$ as a product of coagulation. Total median particle number concentration was $4.8 \times 10^{4}$ particles $/ \mathrm{cm}^{3}\left(\mathrm{IQR} 3.1 \times 10^{4}\right.$ to $9.0 \times 10^{4}$ particles $/ \mathrm{cm}^{3}$ ), and the highest concentration reached about $2.3 \times 10^{5}$ particles $/ \mathrm{cm}^{3}$. The time evolution of larger size bins showed a significant contribution of the smallest size bin to the total number concentration for almost the whole sampling period, except the beginning of the measurement, before the smelting vessel was put into the oven.

Nanocomposite Machining

Operations of mechanical grinding and milling of various nanocomposites produced primary larger particles $>1 \mu \mathrm{m}$, but also, nanoparticles produced by condensation in the colder air far from the machining tool of semivolatile organic compounds and thermal breakdown products generated form localized heating of the polymer during machining. In this case, the measured size distribution exhibited unimodal shape, with a maximum at about $100 \mathrm{~nm}$ with a large tail for supermicron particles. It seems that these particles may have represented the primary particles produced by grinding and milling. Total median particle number concentration was $5.4 \times 10^{5}$ particles $/ \mathrm{cm}^{3}$ (IQR $3.1 \times 10^{5}$ to $6.8 \times 10^{5}$ particles $/ \mathrm{cm}^{3}$ ), with maximum concentration around $8.8 \times 10^{5}$ particles $/ \mathrm{cm}^{3}$.

Nevertheless, comparison of the process data with the background measurement in the same workshop floor suggests contribution of other sources of particles. Time plots of the larger size bins revealed that the highest contribution to the total number concentration was from the accumulation mode particles $(100 \mathrm{~nm}-1 \mu \mathrm{m})$.

\section{Background}

All the measurements of the background values showed high particle concentrations, which might have considerably influenced the measurements, making the estimation of the contribution of individual sources very complex. The background values were measured first during the night in the corridor next to the workshops. Then, before each working operation, $15 \mathrm{~min}$ of measurements were taken as background values. There were no other obvious sources of aerosol background particles, except from indoor penetration of outdoor particles. Particle number size distributions during the operations are shown in Supplementary Figures S1 and S2.

The percentage of total particulate number concentrations $(<10 \mu \mathrm{m})$ in larger size bins, measured by SMPS and APS (based on aerodynamic diameter) is shown in Table 2. The highest proportion of particles smaller than $100 \mathrm{~nm}$ in diameter was found during machining, whereas the lowest during welding, as can be seen in Table 2. The percentage of total PM number concentrations in larger size bins $(<10 \mu \mathrm{m})$ is presented in Table 3 . 
Table 2. Summary statistics of the number concentration and size distribution of the aerosol during various operations. TNC $=$ total number concentration.

\begin{tabular}{|c|c|c|c|c|c|c|c|}
\hline Operation & $\begin{array}{c}N \text { (Number of } \\
\text { SMPS/APS Samples) }\end{array}$ & $\begin{array}{c}\text { TNC }\left(\text { particles } / \mathrm{cm}^{3}\right), \\
\text { Median }\end{array}$ & $\begin{array}{c}\text { TNC, } \\
\text { Maximum }\end{array}$ & $\begin{array}{l}\text { Size Distribution } \\
\text { (Main Mode) }\end{array}$ & $\begin{array}{c}\% \text { of Particles } \\
<100 \mathrm{~nm}\end{array}$ & $\begin{array}{c}\text { Ratio } \\
\text { Operation/Background }\end{array}$ & $\begin{array}{l}\text { Mass Concentration } \\
\left(\mathrm{mg} / \mathrm{m}^{3}\right)\end{array}$ \\
\hline Smelting & 32 & $4.8 \times 10^{4}$ & $2.0 \times 10^{5}$ & $<25 \mathrm{~nm}$ & 95 & 2.3 & 0.120 \\
\hline Machining & 39 & $5.4 \times 10^{5}$ & $8.2 \times 10^{5}$ & $100 \mathrm{~nm}$ & 61 & 1.9 & 0.804 \\
\hline Welding & 28 & $1.3 \times 10^{5}$ & $2.5 \times 10^{5}$ & $200 \mathrm{~nm}$ & 40 & 6.2 & 1.840 \\
\hline Background smelting/welding & 5 & $2.1 \times 10^{4}$ & $2.5 \times 10^{4}$ & $<10 \mathrm{~nm}$ & 97 & 1 & not measured \\
\hline Background machining & 5 & $2.8 \times 10^{5}$ & $3.4 \times 10^{5}$ & $130 \mathrm{~nm}$ & 41 & 1 & not measured \\
\hline
\end{tabular}

Table 3. Percentage of total PM number concentrations $(<10 \mu \mathrm{m})$ in larger size bins measured by SMPS and APS (based on aerodynamic diameter).

\begin{tabular}{|c|c|c|c|c|c|c|c|c|}
\hline \multirow{2}{*}{\multicolumn{2}{|c|}{ Percentage from Total $<10 \mu \mathrm{m}$}} & \multicolumn{2}{|c|}{$<25-100 \mathrm{~nm}$} & \multicolumn{5}{|c|}{$100 \mathrm{~nm}-10 \mu \mathrm{m}$} \\
\hline & & $<25 \mathrm{~nm}$ & $\mathbf{2 5 - 1 0 0 ~ n m ~}$ & $100 \mathrm{~nm}-1 \mu \mathrm{m}$ & $1-2.5 \mu \mathrm{m}$ & $2.5-10 \mu \mathrm{m}$ & Total $<1 \mu \mathrm{m}$ & $1-10 \mu \mathrm{m}$ \\
\hline \multirow{3}{*}{ Basement } & Metal Active Gas (MAG) Welding & 3.35 & 36.78 & 59.85 & 0.02 & 0.00 & 99.97 & 0.03 \\
\hline & Smelting & 69.64 & 25.00 & 5.36 & 0.01 & 0.00 & 99.99 & 0.01 \\
\hline & Background-15 $\mathrm{min}$ before welding & 74.37 & 22.39 & 3.23 & 0.00 & 0.00 & 99.99 & 0.01 \\
\hline \multirow{3}{*}{ Ground floor } & Machining (Milling \& Grinding) & 2.61 & 58.62 & 38.76 & 0.00 & 0.00 & 99.99 & 0.01 \\
\hline & Background-15 min before machining & 0.27 & 40.62 & 59.10 & 0.01 & 0.00 & 99.99 & 0.01 \\
\hline & 3ackground-night-15 h & 4.24 & 66.40 & 29.32 & 0.04 & 0.00 & 99.96 & 0.04 \\
\hline
\end{tabular}




\subsubsection{Mass Size Distributions}

The highest mass concentration measured by BLPI was found during welding, with mean $1.840 \mathrm{mg} / \mathrm{m}^{3}$, the second highest during machining, with $0.804 \mathrm{mg} / \mathrm{m}^{3}$, and the lowest during smelting, with $0.120 \mathrm{mg} / \mathrm{m}^{3}$. Fine mode peaked at around $300 \mathrm{~nm}$ in aerodynamic diameter during welding and smelting, when the mass size distributions were almost monomodal, while during machining it peaked at about $200 \mathrm{~nm}$ with bimodal mass size distribution, as can be seen in Figure 1.

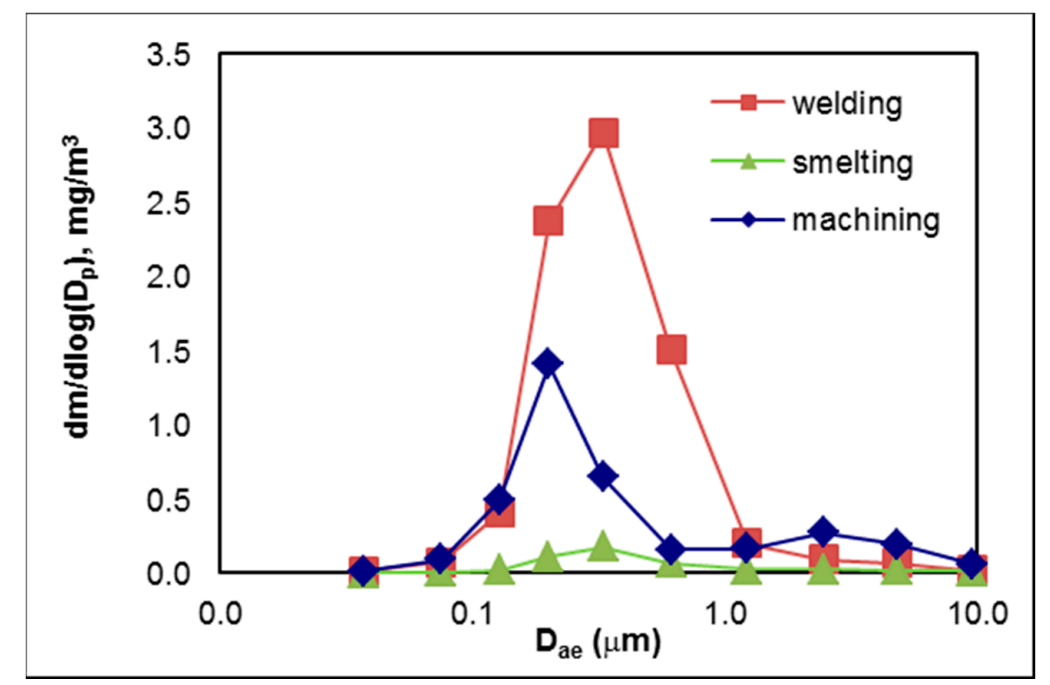

Figure 1. Mass size distribution of aerosol particles produced during welding, smelting, and machining. Values determined by gravimetric analysis of samples collected with the Berner low-pressure cascade impactor (BLPI).

\subsubsection{Size-Resolved Elemental Composition}

In the case of welding, the particles were dominated by iron, manganese, and silicon, with manganese and silicon being enriched in comparison with welded material. The maximum of size distribution was between 247 and $435 \mathrm{~nm}$ in aerodynamic diameter both for manganese and iron. Silicon concentration was the largest for the biggest analyzed particles.

Smelting operation was done in the same workshop as welding, and despite intensive venting after the previous operation, the analyzed aerosol captured most of signatures of particles from welding. Therefore, the particles were again dominated by iron, manganese, and silicon. Some influence of smelting was visible, especially on last stage, with size range $25-56 \mathrm{~nm}$ where aluminum, sodium, and chloride were enriched. The mass size distribution had the same features as from welding. Due to an approximately $30 \times$ dilution of aerosol from welding, some influence of ambient aerosol was visible, especially based on sulfur concentrations.

Elemental composition of size-resolved aerosol fractions during the three operations are shown in Figures 2-4.

The data from machining of geopolymers exhibited the largest variability in elemental composition, suggesting a more complex range of sources. Moreover, the total elemental analyzed mass was only a few percent of the total mass, while in previous operations, it accounted for $\sim 50 \%$ of the total mass.

We have attempted to calculate the missing mass as a difference between the total mass determined gravimetrically, and sum of all analyzed ions $+\mathrm{Al}, \mathrm{Si}, \mathrm{Ti}, \mathrm{Fe}, \mathrm{Mn}$, where analyzed elements were represented by their oxides $\left(\mathrm{Al}_{2} \mathrm{O}_{3}, \mathrm{SiO}_{2}, \mathrm{TiO}_{2}, \mathrm{Fe}_{2} \mathrm{O}_{3}, \mathrm{MnO}_{2}\right)$. Based on our experience from similar past experiments, the missing mass was most probably composed of carbonaceous matter. In the nanofraction, i.e., lowest two impactor stages with particle aerodynamic diameters 25-56 and 56-100 nm, the missing mass formed over 95\% of the total mass. 

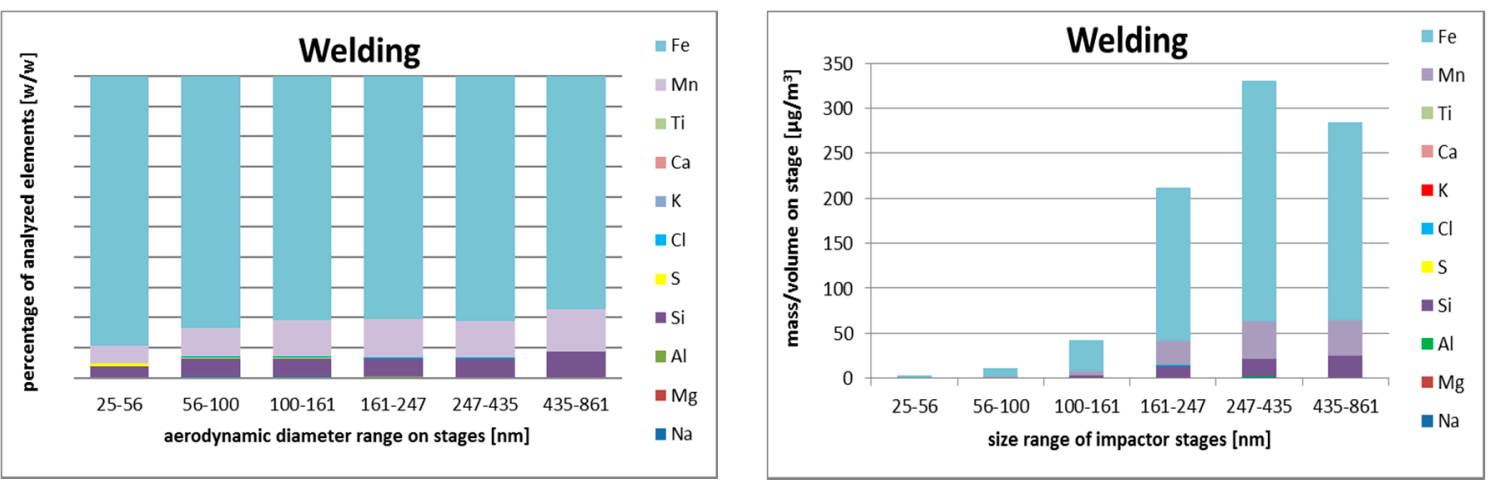

Figure 2. SEM/EDS relative (left) and absolute (right) elemental composition of size-resolved aerosol fractions during welding, based on samples obtained by Berner low-pressure cascade impactor (BLPI), in the range from $25 \mathrm{~nm}$ to $860 \mathrm{~nm}$ (six lowest stages, aerodynamic diameter).
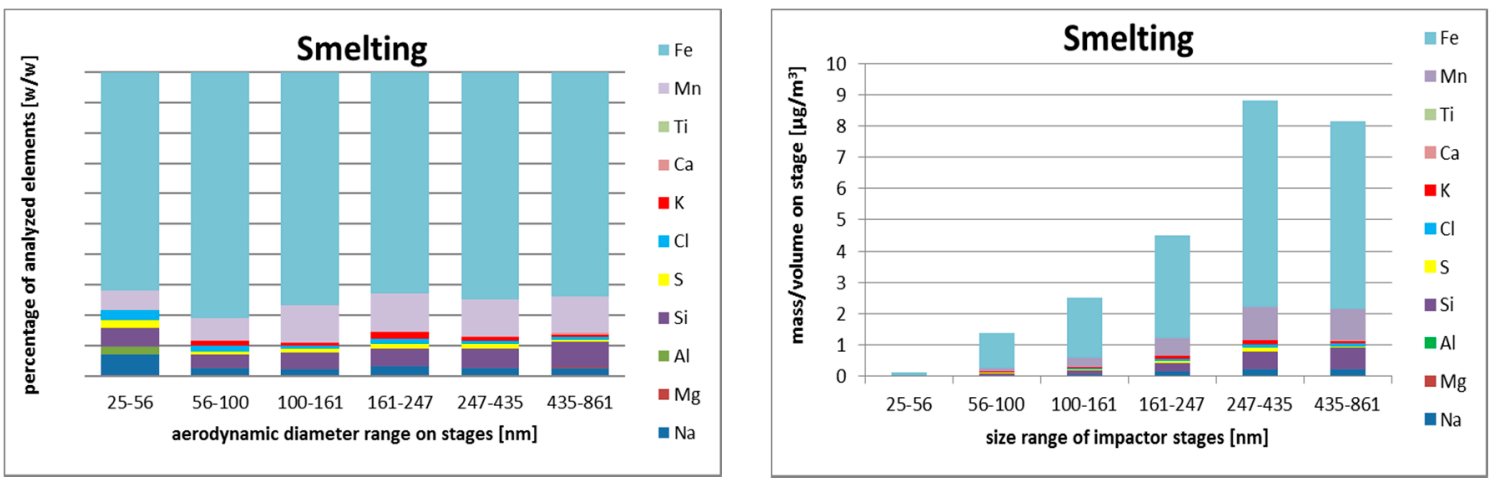

Figure 3. SEM/EDS relative (left) and absolute (right) elemental composition of size-resolved aerosol fractions during smelting based on samples obtained by Berner low-pressure cascade impactor (BLPI), in the range from $25 \mathrm{~nm}$ to $860 \mathrm{~nm}$ (six lowest stages, aerodynamic diameter).
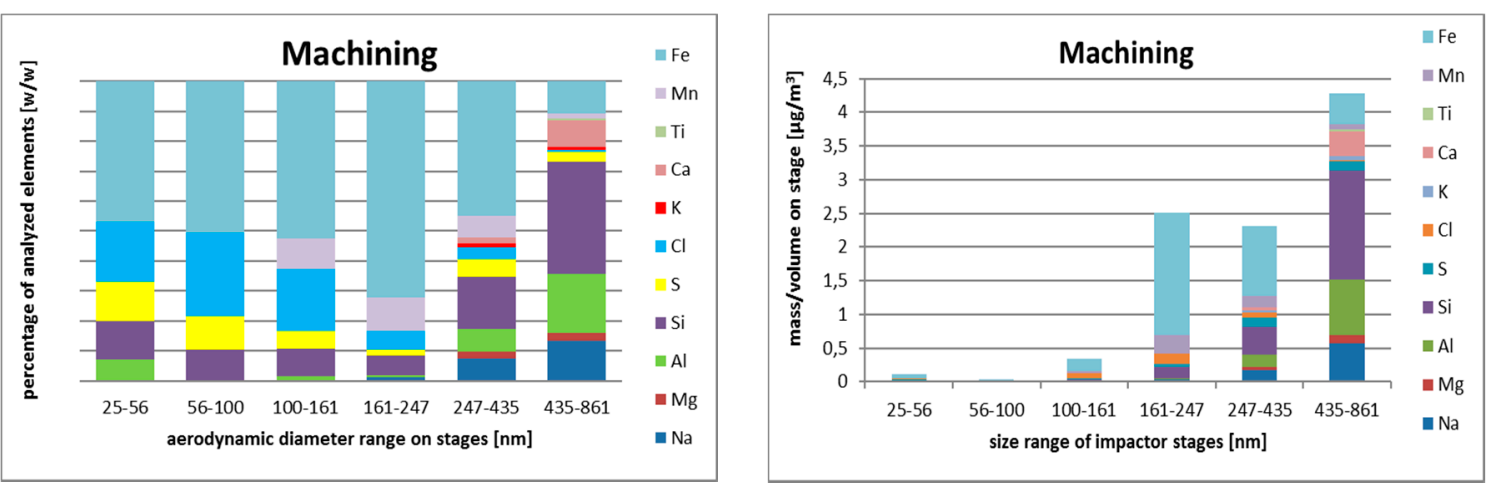

Figure 4. SEM/EDS relative (left) and absolute (right) elemental composition of size-resolved aerosol fractions during machining based on samples obtained by Berner low-pressure cascade impactor (BLPI), in the range from $25 \mathrm{~nm}$ to $860 \mathrm{~nm}$ (six lowest stages, aerodynamic diameter).

Concerning metals, the smallest particles were rich with iron, chlorine, silicon, and sulfur. Iron and manganese were more abundant in the aerodynamic diameter size range 161-247 nm. The larger particles contained higher concentrations of silicon, aluminum, and sodium. The data in Table 4 show dominance of iron and manganese in first two operations (welding and smelting). 
Table 4. Elemental mass concentration during various operations and diagnostic ratios.

\begin{tabular}{ccccccccc}
\hline \multirow{2}{*}{ Operation } & \multicolumn{9}{c}{ Mass Concentration $\left(\mu \mathrm{g} / \mathbf{m}^{3}\right)$} & \multicolumn{3}{c}{ Diagnostic Ratios } \\
\cline { 2 - 9 } & $\mathbf{F e}$ & $\mathbf{M n}$ & $\mathrm{Ti}$ & $\mathrm{Ca}$ & $\mathrm{Si}$ & $\mathbf{M g}$ & $\mathbf{M n} / \mathbf{F e}$ & $\mathrm{Si} / \mathrm{Fe}$ \\
\hline Welding & 703 & 114 & 0 & 0 & 59 & 0 & 0.16 & 0.08 \\
Smelting & 19 & 3.00 & 0 & 0.04 & 1.70 & 0.01 & 0.16 & 0.09 \\
Machining & 3.60 & 0.55 & 0.03 & 0.42 & 2.20 & 0.17 & 0.16 & 0.63 \\
\hline
\end{tabular}

\subsection{Oxidative Stress Markers in EBC}

In all samples, the markers measured were above the limit of quantitation. No influence of the conductivity on EBC markers' levels was found. Amylase concentrations in the EBC of all subjects was less than $0.01 \%$ of that in saliva [32].

No significant decrease was found in EBC markers with increasing latency from last exposure. Similarly, no difference was found between researchers who switched workshops in the previous days or weeks (except 8-isoprostane, that was higher in researchers who continuously worked in workshop $2, p<0.05)$.

\subsubsection{Markers of Oxidation of Lipids}

The markers of oxidation of lipids in the whole group of researchers are shown in Figure 5. Only pre-shift MDA and aldehydes $\mathrm{C}_{6}-\mathrm{C}_{13}$ were significantly higher in the researchers than controls. However, all post-shift markers derived from the oxidation of lipids, except HHE, were elevated compared to the controls.

A statistically significant increase was seen for all markers of lipid oxidation in post-shift samples relative to pre-shift: $\mathrm{MDA}, \mathrm{HNE}, \mathrm{HHE}$, aldehydes $\mathrm{C}_{6}-\mathrm{C}_{13}$, and 8-isoprostane.

The same markers in the researchers in the subgroups exposed in workshop 1 and workshop 2 are shown in Supplementary Figure S3. The only marker that showed both a pre-shift and post-shift elevation in workshop 2, as compared to workshop 1, was 8-isoprostane; other markers did not differ significantly between the workshops.

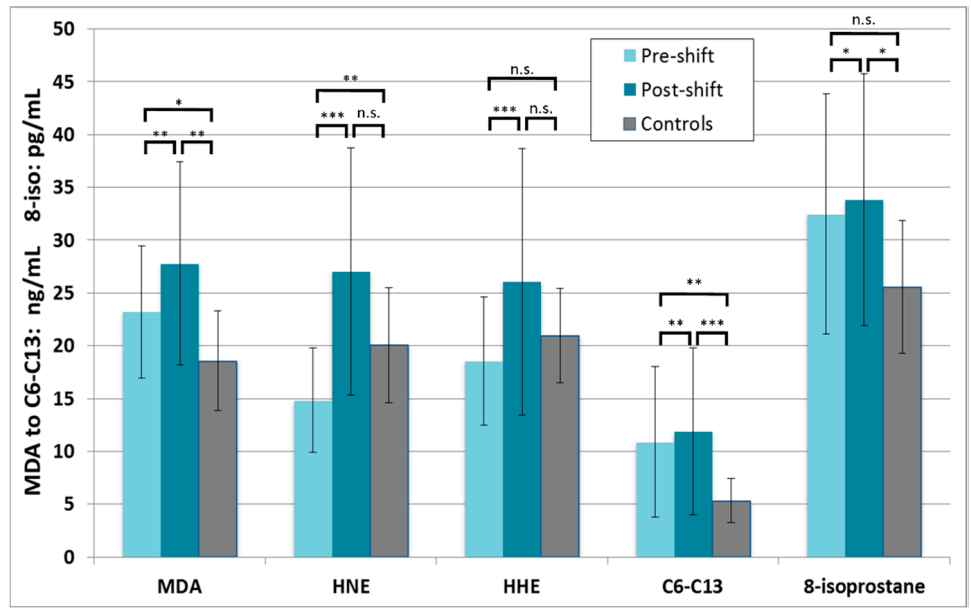

Figure 5. Markers of oxidation of lipids in all 19 nanocomposite workers in pre-shift and post-shift samples) in comparison with controls, ${ }^{*} p<0.05,{ }^{* *} p<0.01,{ }^{* * *} p<0.001$, MDA = malondialdehyde, HNE $=4$-hydroxy-trans-nonenal, $\mathrm{HHE}=4$-hydroxy-trans-hexenal, $\mathrm{C}_{6}-\mathrm{C}_{13}=$ aldehydes $\mathrm{C}_{6}-\mathrm{C}_{13}$, 8-isoprostane $=8$-iso-prostaglandin F2 $\alpha$.

\subsubsection{Markers of Oxidation of Nucleic Acids and Proteins}

In contrast to lipid oxidation markers, all markers of oxidation of nucleic acids and proteins were already significantly elevated in the pre-shift EBC samples, and no further increase was observed in 
post-shift EBC samples (Figure 6). The same markers in the researchers in the subgroups exposed in workshop 1 and workshop 2 are shown in Supplementary Figure S4. No significant differences between the workshops were seen.

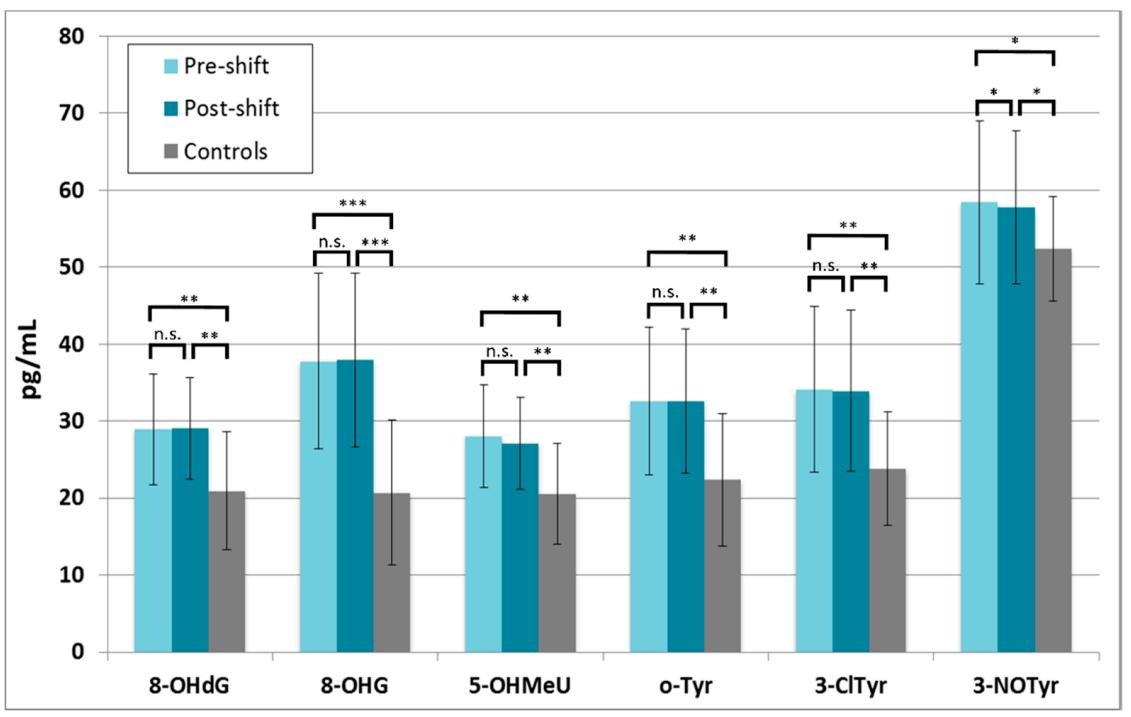

Figure 6. Markers of oxidation of nucleic acids and proteins in all 19 nanocomposites workers in pre-shift and post-shift samples in comparison with the controls, ${ }^{*} p<0.05,{ }^{* *} p<0.01,{ }^{* * *} p<0.001$, 8-OHdG = 8-hydroxy-2-deoxyguanosine, 8-OHG = 8-hydroxyguanosine, 5-OHMeU = 5-hydroxymethyl uracil, $o$-Tyr $=o$-tyrosine, 3 -ClTyr $=3$-chlorotyrosine, 3-NOTyr $=3$-nitrotyrosine.

\subsubsection{Correlations of Markers with Exposure and Symptoms}

Two markers, namely 5-OHMeU and $o-\mathrm{Tyr}$, were correlated with the years of employment in these operations. Post-shift 3-NOTyr correlated with chronic bronchitis, defined as chronic, productive cough for three months in each of two consecutive years [33], as can be seen in Table 5.

Table 5. Correlations of pre-shift and post-shift exhaled breath condensate (EBC) markers with the length of exposure and chronic bronchitis in the researchers exposed to nanocomposites.

\begin{tabular}{ccc}
\hline & $\begin{array}{c}\text { Pre-Shift Marker, Correlation } \\
\text { Coefficient }(p \text { Value) }\end{array}$ & $\begin{array}{c}\text { Post-Shift Marker, Correlation } \\
\text { Coefficient }(p \text { Value) }\end{array}$ \\
\hline $\begin{array}{c}\text { Employment in nanocomposite } \\
\text { production (years) }\end{array}$ & $5-\mathrm{OHMeU}, 0.477(0.039)$ & - \\
Chronic bronchitis & $0-\mathrm{Tyr}, 0.488(0.034)$ & $o-\mathrm{Tyr}, 0.511(0.025)$ \\
\hline
\end{tabular}

\subsubsection{Correlations of the Levels of Markers in the Pre-Shift and Post-Shift Samples}

The level of the majority of markers in the pre-shift collection correlated with the identical markers in the post-shift samples. In addition, the level of a large number of biomarkers correlated with the level of other biomarkers in the same or in the other samples, as presented in Supplementary Table S2.

\subsubsection{Association of EBC Markers with Occupational Exposure}

Multiple regression analysis confirmed a significant association $(p<0.05)$ between production and machining of nanocomposites in nine pre-shift and nine post-shift markers, as shown in Tables 6 and 7. Non-occupational factors were generally not significantly associated with EBC biomarkers. 
Table 6. Multiple regression analysis (regression coefficient and 95\% CI) of nanocomposite exposure, age, gender, alcohol, body mass index (BMI), and pre-shift oxidative stress markers in the exhaled breath condensate. $\mathrm{C}_{6}-\mathrm{C}_{13}=$ aldehydes $\mathrm{C}_{6}-\mathrm{C}_{13}, 8$-OHdG $=8$-hydroxy-2-deoxyguanosine, 8-OHG $=8$-hydroxyguanosine, 5-OHMeU = 5-hydroxymethyl uracil, $o$-Tyr $=o$-tyrosine, 3-ClTyr $=3$-chlorotyrosine, 3-NOTyr $=3$-nitrotyrosine. ${ }^{*} p<0.05,{ }^{* *} p<0.01,{ }^{* * *} p<0.001$.

\begin{tabular}{|c|c|c|c|c|c|c|c|c|c|}
\hline Pre-Shift Markers & MDA & $\mathrm{C}_{6}-\mathrm{C}_{13}$ & 8-isoprostane & 8-OHdG & 8-OHG & 5-OHMeU & $o$-Tyr & 3-ClTyr & 3-NOTyr \\
\hline Nanocomposites production (Yes/No) & $\begin{array}{c}4.71 * \\
(1.19,8.23)\end{array}$ & $\begin{array}{c}\mathbf{7 . 0 6} * * * \\
(3.58,10.54)\end{array}$ & $\begin{array}{c}\mathbf{8 . 0 2} * \\
(1.36,14.69)\end{array}$ & $\begin{array}{c}\mathbf{8 . 6 1} 1^{* *} \\
(3.26,13.97)\end{array}$ & $\begin{array}{c}17.66^{* * *} \\
(9.97,23.35)\end{array}$ & $\begin{array}{c}7.46^{* *} \\
(2.82,12.09)\end{array}$ & $\begin{array}{c}10.12 * * \\
(3.64,16.59)\end{array}$ & $\begin{array}{c}11.31 \text { *** } \\
(5.00,17.61)\end{array}$ & $\begin{array}{c}\mathbf{6 . 7 4}{ }^{*} \\
(0.36,13.12)\end{array}$ \\
\hline Age (years) & $\begin{array}{c}-\mathbf{0 . 2 3} 3^{* *} \\
(-0.40,-0.70)\end{array}$ & $\begin{array}{c}0.53 \\
(-0.11,0.22)\end{array}$ & $\begin{array}{c}0.03 \\
(-2.29,0.34)\end{array}$ & $\begin{array}{c}0.10 \\
(-0.15,0.35)\end{array}$ & $\begin{array}{c}0.11 \\
(-0.25,0.47)\end{array}$ & $\begin{array}{c}0.18 \\
(-0.04,0.39)\end{array}$ & $\begin{array}{c}0.17 \\
(-0.13,0.47)\end{array}$ & $\begin{array}{c}\mathbf{0 . 3 4}{ }^{*} \\
(0.44,0.63)\end{array}$ & $\begin{array}{c}-0.02 \\
(-0.31,0.28)\end{array}$ \\
\hline Gender (Male/Female) & $\begin{array}{c}0.73 \\
(-3.56,5.01) \\
\end{array}$ & $\begin{array}{c}-0.84 \\
(-5.07,3.40) \\
\end{array}$ & $\begin{array}{c}0.10 \\
(-8.01,8.21) \\
\end{array}$ & $\begin{array}{c}4.00 \\
(-2.51,10.52) \\
\end{array}$ & $\begin{array}{c}1.96 \\
(-7.40,11.31) \\
\end{array}$ & $\begin{array}{c}2.38 \\
(-3.27,8.02) \\
\end{array}$ & $\begin{array}{c}5.61 \\
(-2.26,13.49) \\
\end{array}$ & $\begin{array}{c}3.92 \\
(-3.76,11.60) \\
\end{array}$ & $\begin{array}{c}4.34 \\
(-3.42,12.10) \\
\end{array}$ \\
\hline Alcohol (Yes/No) & $\begin{array}{c}-1.53 \\
(-7.18,4.11)\end{array}$ & $\begin{array}{c}2.61 \\
(-2.97,8.18) \\
\end{array}$ & $\begin{array}{c}3.79 \\
(-6.89,14.47) \\
\end{array}$ & $\begin{array}{c}3.73 \\
(-4.85,12.31) \\
\end{array}$ & $\begin{array}{c}3.50 \\
(-8.83,15.82) \\
\end{array}$ & $\begin{array}{c}4.59 \\
(-2.84,12.03) \\
\end{array}$ & $\begin{array}{c}4.63 \\
(-5.74,15.00) \\
\end{array}$ & $\begin{array}{c}2.72 \\
(-7.39,12.83) \\
\end{array}$ & $\begin{array}{c}2.73 \\
(-7.49,12.94) \\
\end{array}$ \\
\hline BMI $\left(\mathrm{kg} / \mathrm{m}^{2}\right)$ & $\begin{array}{c}-0.83 \\
(-0.45,0.28)\end{array}$ & $\begin{array}{c}-0.38^{*} \\
(-0.74,-0.20)\end{array}$ & $\begin{array}{c}-0.28 \\
(-0.97,0.40)\end{array}$ & $\begin{array}{c}-0.25 \\
(-0.80,0.31)\end{array}$ & $\begin{array}{c}-0.18 \\
(-0.97,0.62)\end{array}$ & $\begin{array}{c}0.26 \\
(-0.45,0.51)\end{array}$ & $\begin{array}{c}-0.07 \\
(-0.74,0.60)\end{array}$ & $\begin{array}{c}-0.37 \\
(-1.02,0.28)\end{array}$ & $\begin{array}{c}-0.30 \\
(-0.96,0.36)\end{array}$ \\
\hline
\end{tabular}

Table 7. Multiple regression analysis (regression coefficient and 95\% CI) of nanocomposite exposure, age, gender, alcohol, body mass index (BMI), and post-shift markers of oxidation in the exhaled breath condensate. MDA $=$ malondialdehyde, $\mathrm{HNE}=4$-hydroxy-trans-nonenal, $\mathrm{C}_{6}-\mathrm{C}_{13}=$ aldehydes $_{6}-\mathrm{C}_{13}, 8$-isoprostane $=$ 8-iso-prostaglandin F2 $\alpha$, 8-OHdG = 8-hydroxy-2-deoxyguanosine, 8-OHG = 8-hydroxyguanosine, 5-OHMeU = 5-hydroxymethyl uracil, $o$-Tyr = o-tyrosine, 3-ClTyr = 3-chlorotyrosine. ${ }^{*} p<0.05,{ }^{* *} p<0.01,{ }^{* * *} p<0.001$.

\begin{tabular}{|c|c|c|c|c|c|c|c|c|c|}
\hline Post-Shift Markers & MDA & HNE & $\mathrm{C}_{6}-\mathrm{C}_{13}$ & 8-isoprostane & 8-OHdG & 8-OHG & 5-OHMeU & o-Tyr & 3-ClTyr \\
\hline Nanocomposites production (Yes/No) & $\begin{array}{c}8.71^{* *} \\
(4.33,14.00)\end{array}$ & $\begin{array}{c}8.48^{* *} \\
(2.20,14.75)\end{array}$ & $\begin{array}{c}8.27^{* * *} \\
(4.47,12.08)\end{array}$ & $\begin{array}{c}\mathbf{9 . 3 7} \text { ** } \\
(2.44,16.31)\end{array}$ & $\begin{array}{c}8.23^{* *} \\
(3.00,13.47)\end{array}$ & $\begin{array}{c}17.78^{* * *} \\
(10.12,25.43)\end{array}$ & $\begin{array}{c}\mathbf{5 . 7 4} 4^{* *} \\
(1.21,10.27)\end{array}$ & $\begin{array}{c}10.27^{* *} \\
(3.88,16.65)\end{array}$ & $\begin{array}{c}11.09^{* * *} \\
(4.88,17.31)\end{array}$ \\
\hline Age (years) & $\begin{array}{c}-0.20 \\
(-0.45,0.49) \\
\end{array}$ & $\begin{array}{c}0.18 \\
(-0.28,0.31) \\
\end{array}$ & $\begin{array}{c}0.05 \\
(-0.13,0.23) \\
\end{array}$ & $\begin{array}{c}0.05 \\
(-0.28,0.37) \\
\end{array}$ & $\begin{array}{c}-0.05 \\
(-0.29,0.20) \\
\end{array}$ & $\begin{array}{c}0.11 \\
(-0.25,0.47) \\
\end{array}$ & $\begin{array}{c}-0.03 \\
(-0.24,0.19) \\
\end{array}$ & $\begin{array}{c}0.17 \\
(-0.13,0.47) \\
\end{array}$ & $\begin{array}{c}\mathbf{0 . 3 3} \text { * } \\
(0.04,0.62)\end{array}$ \\
\hline Gender (Male/Female) & $\begin{array}{c}2.33 \\
(-4.10,8.76) \\
\end{array}$ & $\begin{array}{c}6.06 \\
(-1.58,13.70) \\
\end{array}$ & $\begin{array}{c}-0.66 \\
(-5.29,4.00) \\
\end{array}$ & $\begin{array}{c}0.18 \\
(-8.26,8.62) \\
\end{array}$ & $\begin{array}{c}2.09 \\
(-4.28,8.45) \\
\end{array}$ & $\begin{array}{c}1.70 \\
(-7.62,11.01) \\
\end{array}$ & $\begin{array}{c}1.55 \\
(-3.96,7.06) \\
\end{array}$ & $\begin{array}{c}5.52 \\
(-2.25,13.29) \\
\end{array}$ & $\begin{array}{c}3.73 \\
(-3.84,11.29) \\
\end{array}$ \\
\hline Alcohol (Yes/No) & $\begin{array}{c}-0.88 \\
(-9.34,7.58) \\
\end{array}$ & $\begin{array}{c}2.15 \\
(-7.91,12,21)\end{array}$ & $\begin{array}{c}2.81 \\
(-3.28,8.90) \\
\end{array}$ & $\begin{array}{c}3.10 \\
(-8.01,14.21)\end{array}$ & $\begin{array}{c}1.34 \\
(-7.05,9.72)\end{array}$ & $\begin{array}{c}3.32 \\
(-8.94,15.59) \\
\end{array}$ & $\begin{array}{c}1.79 \\
(-5.47,9.05) \\
\end{array}$ & $\begin{array}{c}4.75 \\
(-5.48,14.98) \\
\end{array}$ & $\begin{array}{c}2.63 \\
(-7.34,12.59) \\
\end{array}$ \\
\hline BMI $\left(\mathrm{kg} / \mathrm{m}^{2}\right)$ & $\begin{array}{c}0.06 \\
(-0.49,0.60)\end{array}$ & $\begin{array}{c}-0.61 \\
(-1.25,0.42)\end{array}$ & $\begin{array}{c}-\mathbf{0 . 4 5} \\
(-0.84,-0.05)\end{array}$ & $\begin{array}{c}-0.29 \\
(-1.01,0.43)\end{array}$ & $\begin{array}{c}-0.09 \\
(-0.63,0.45)\end{array}$ & $\begin{array}{c}-0.16 \\
(-0.95,0.63)\end{array}$ & $\begin{array}{c}0.23 \\
(-0.24,0.70)\end{array}$ & $\begin{array}{c}-0.93 \\
(-0.75,0.57)\end{array}$ & $\begin{array}{c}0.36 \\
(-1.01,0.28)\end{array}$ \\
\hline
\end{tabular}




\subsection{Environmental Contamination}

The level of air pollution with $\mathrm{SO}_{2}, \mathrm{NO}_{x}, \mathrm{O}_{3}, \mathrm{PM}_{2.5}$, and $\mathrm{PM}_{10}$ at both sites was classified by the National Hydrometeorological monitoring system as very low or low. The values did not exceed the recommended limits. No positive correlation of both pre-shift and post-shift markers of oxidative stress with environmental levels was seen.

\section{Discussion}

A large number of nanomaterials has been found in experimental studies to induce toxicity mediated by reactive oxygen species in many biological systems [19]. Reactive oxygen species can attack lipids, nucleic acids, proteins, and further essential biomolecules. This process finally damages mitochondrial structure, causes depolarization of mitochondrial membrane, impairment of the electron transport chain, and the activation of the NADPH-like system. Reduced levels of antioxidants then lead to cellular injury or death by the alteration of signaling pathways. DNA injuries, with single-strand and double-strand breakages were seen, with consequent cell cycle arrest or apoptosis [34,35]. Obviously, these processes are not specific to exposure to nanomaterials.

Although production of the nanocomposites in this research plant included the addition of nanoparticles ( nanoSiO$_{2}$ ), the main proportion of nanoparticles in workplace aerosol originated during machining and smelting of the samples using abrasive structures to modify the surface of the products or at hot temperature. Iron represented the highest proportion of elements detected in the aerosol during all operations monitored, including machining. Similarly, when the elements were ranked according to their mass concentrations in the nanosized fractions (last two impactor stages), Fe was the more abundant element, followed by $\mathrm{Mn}, \mathrm{Si}, \mathrm{Al}, \mathrm{S}, \mathrm{Na}, \mathrm{Cl}$, and $\mathrm{K}$. This means that even though nanoSiO${ }_{2}$ was added in substantial amounts into the machined polymeric materials, its release into the form of nanosized aerosol particles was not as significant. We presume that most of the aerosol mass during machining operation was likely composed of organic compounds, as shown in several of our previous studies [1,2,4], which was not quantifiable in SEM/EDS analysis. When elements are ranked according to their summed mass concentrations over the last six stages of the impactor (from 25 to $860 \mathrm{~nm}$ ), the elements were present in the following descending order of abundance: $\mathrm{Fe}$, $\mathrm{Mn}, \mathrm{Si}, \mathrm{Na}, \mathrm{S}, \mathrm{Cl}, \mathrm{Al}, \mathrm{Ca}, \mathrm{K}, \mathrm{Mg}$, and Ti, for all three operations. Elements other than iron originated mostly from geopolymers and epoxide resins during machining of the surface. It has been shown that composite synthesis generates semivolatile organic compounds, especially related to additives in the polymer $[3,4,36]$. In regard to exposures, our findings are broadly consistent with this prior work. Of course, other substances that are specifically toxic and generated in combustion processes like welding and smelting, including e.g., ozone, may have substantially contributed to the analyzed effects.

Exposure to airborne aerosols in this sector are to mixtures. Even though some Fe oxides are safe for specific biomedical applications, other uses need to be considered more carefully. The adverse toxicological outcomes across different testing platforms are not consistent, and it seems that the nanoparticle coating and protein corona effects may alter nanoparticle dissolution rate, as well as clearance and translocation biokinetics, and make them less toxic [37]. This, however, is not the case in the manufacturing and machining of nanocomposites containing metal oxides, including Fe oxides.

The results of elevated markers of oxidative stress agree with our previous findings in other production plants, where workers were exposed to poorly soluble engineered metal oxide nanoparticles. The highest levels of lipids, nucleic acids, and protein markers of oxidative stress reached about $130 \%$ of the values reported here [38]. In those nanoTiO $\mathrm{T}_{2}$ production workers, median mass and number concentrations were the highest $\left(0.65 \mathrm{mg} / \mathrm{m}^{3}\right.$ and $2.3 \times 10^{4}$ particles $/ \mathrm{cm}^{3}$, respectively) and exposures in the workshop were longer $(3.5 \mathrm{~h} /$ day, with the rest of the shifts spent in the neighboring operating rooms with no exposure to nanoTiO ${ }_{2}$ ) [39]. The length of the shift was also longer in Fe oxide manufacturing plants, with median gravimetric and number concentrations of $0.083 \mathrm{mg} / \mathrm{m}^{3}$ and $6.7 \times 10^{4}$ particles $/ \mathrm{cm}^{3}$, respectively. The results of most markers of oxidation of lipids, nucleic acids, and proteins in the Fe oxide study were 110-120\% higher than in nanocomposite researchers [40]. 
The aerosol mass and number concentrations were higher in this study of nanocomposite workers than in our earlier studies of nanoTiO ${ }_{2}$ and iron oxide manufacturing workers, but the duration of the operations associated with nanoparticle exposures was shorter, typically $<2 \mathrm{~h} /$ day, with the remainder of the shift spent in offices in another part of the building. Another important consideration is that in previous factories, the proportion of the nano-sized particles in the inhaled aerosol was high (80-85\%), whereas in the current study, it was lower and more variable (40-95\%). Even in the office, in the employees who visited the $\mathrm{TiO}_{2}$ production area and were exposed to the aerosol for an average of $14 \mathrm{~min} /$ day, the EBC markers reached $50-60 \%$ of the levels measured in $\mathrm{TiO}_{2}$ production workers, which was significantly higher when compared to controls [41,42].

No association was seen with lifestyle factors or environmental air contamination in any of the studies, including this one.

Of note, EBC markers of oxidative stress in this study were already elevated in pre-shift samples, suggesting chronic effects. Accordingly, in our previous study, the pre-shift markers were elevated [38], and $\mathrm{TiO}_{2}$ particles were identified in the pre-shift EBC samples of the workers [43]. The biokinetics of tissue recovery from previous injury in humans, in the absence of further exposure, is not well documented in these cohorts of workers, but it is likely that these effects can last for months to years. In a short inhalational study using $10 \mathrm{mg} / \mathrm{m}^{3}$ nanoTiO ${ }_{2}$ in rats over 2 weeks ( $6 \mathrm{~h} /$ day, 5 days/week), histopathological lesions persisted at post-exposure day 7, but resolved at day 15 [44].

Furthermore, other human studies brought results supporting the potential of nanoparticles to produce oxidative stress in human volunteers [45-49]. Current research on health effects and epidemiology of nanomanufacturing workers, focusing on the respiratory system and its closely associated cardiovascular system and circulation, is limited. However, Liou et al. [50,51] recently found significantly higher 8-isoprostane in $\mathrm{EBC}$ and 8-OHdG in the urine of workers with occupational exposure to metal oxide nanomaterials $\left(\mathrm{TiO}_{2}, \mathrm{SiO}_{2}\right.$, or indium tin oxide). In a recent study of workers exposed to high levels of nanoTiO 2 , Zhao et al. (2018) documented elevated cardiopulmonary disease markers, impairment of lung function, X-ray interstitial changes, and elevated blood MDA and TNF biomarkers that were associated with occupational exposure [52]. In the current group of nanocomposite researchers, we have found borderline post-shift spirometry impairments, more frequent chronic bronchitis, as well as increased pro-inflammatory markers of lung injury, such as cytokines and leukotrienes [24]. This is also in agreement with the results in employees of photocopy workstations [53].

One major limitation of this study is the small number of subjects, which unfortunately, is limited by the small size of this workforce, as all available research workers were included. This is a common issue in epidemiological studies of nanomanufacturing workers because the industry is still evolving, consolidating, and changing all the time. Secondly, aerosol measurements were based on area sampling, not personal exposures, as good quality personal nanoparticle samplers were not available at the time of this field study. Another challenge is the mixed nature of exposures, which makes it difficult to discern effects resulting from engineered nanoparticles, incidental ones, nanocomposite synthesis and processing, or auxiliary operations such as welding. As has already been mentioned, other substances specifically generated in combustion processes, such as welding and smelting, like e.g., ozone, carbon monoxide, and polycyclic aromatic hydrocarbon, are likely to be causal for the effects analyzed.

Due to limited access to the workplace, we could only collect a relatively small number of measurements. We acknowledge limited characterization of exposure variability in the current study. Although aerosol exposures were well characterized for each operation, day-to-day and seasonal variability due to variations in operations, working conditions, and activities, requires repeated measures. Furthermore, we do not have a good explanation for the high background exposure levels measured in some cases, although persisting nanoparticles in background air from past working operations cannot be excluded. This study is ongoing, and these limitations will be addressed in follow-up visits. Exposure sources in individual workshops/laboratories were usually mixed, and it is difficult to apportion aerosol source contribution to the overall nanoparticle exposures. 
A notable strength of our study is the large spectrum of biomarkers and clinical endpoints that were examined. Consistency in study design and biomarker endpoints across several studies of nanoparticle-exposed workers further enabled us to examine relationships between pre-shift and post-shift biomarkers in EBC, and identify the more robust biomarkers for biomonitoring purposes. Due to frequent correlation between the pre-shift and post-shift markers in this study, we could limit EBC collection to the post-shift samples. Furthermore, by exploring the patterns of biomarker from our earlier studies and the strength of association in multiple regression analysis, we could narrow the broad spectrum of markers of oxidation to the following markers that appeared to be the most robust set of markers across all our studies: $8-\mathrm{OHdG}$ and 5-OHMeU from nucleic acids; 0 -Tyr and 3-NOTyr from proteins; and MDA, and ALD6-12 from lipids. We will also keep 8-isoprostane, a biomarker that differentiated the subgroups of researchers (higher in workshop 2 during machining of nanocomposites) in subsequent investigations.

One major challenge with sensitive biomonitoring techniques is their limited specificity towards exposure triggers and the difficulty in interpreting the meaning of their physiological values in the context of chronic disease development and damage-repair kinetics. It is likely the transition metals, especially $\mathrm{Fe}$ and $\mathrm{Mn}$ and their dissolved ions, contribute significantly to oxidative stress in lung tissues [15,34]. Similarly elevated oxidative stress markers in EBC have been seen in patients exposed to asbestos and silica [54-56]. The contribution of organics and biopersistent polymeric particles in oxidative stress and inflammatory responses, in this cohort of workers, cannot be ruled out.

\section{Conclusions}

Our results are consistent with the oxidative stress hypothesis, and suggest lung injury at the molecular level. Researchers in nanocomposite processing had elevated levels of oxidative stress markers in EBC. In a companion manuscript, we also report on elevated levels of inflammatory markers in EBC and chronic bronchitis among this cohort of workers. These effects are likely caused by mixed exposures to aerosols, originating from welding, smelting, and nanocomposite processing.

More research is needed, as other substances generated in combustion processes, including welding and smelting, like e.g., ozone, or polycyclic aromatic hydrocarbons in both workshops, should be evaluated.

Considering that exposures in this study were long-term (close to two decades), but of short duration and frequency (no longer than $2 \mathrm{~h}$ /day in total, and often shorter), chronicity of such short exposure episodes is sufficient to trigger chronic oxidative stress and inflammatory responses comparable to the levels of EBC biomarkers found in (nano)Fe oxide nanomanufacturing workers, and of the same order of magnitude (although lower) than in nanoTiO ${ }_{2}$ manufacturing workers who were exposed for longer operation durations over similar periods of time.

We can strongly recommend using both the ventilation system in the workshops and the personal protection equipment of the researchers.

Analysis of exhaled breath has immense potential to bring data enabling monitoring of several exposures from the workplace and the environment where nanoparticles and other inhalable toxicants may play a significant role. We recommend post-shift analysis of the following markers: 8-OHdG, 5-OHMeU, $o$-Tyr, 3-NOTyr, MDA, ALD6-12, and 8-isoprostane as the most sensitive and robust biomarkers across all our EBC studies.

Supplementary Materials: The following are available online at http:/ /www.mdpi.com/2079-4991/8/8/611/s1.

Author Contributions: D.P., V.Z. and S.D. designed the study; D.P., V.Z., J.S., S.D., J.O., S.V., Z.F., A.P. and L.L. performed the field work; P.K. analyzed the samples; M.K., M.K., V.Z., D.B. and S.Z. analyzed the data; D.P., V.Z. and D.B. wrote the paper.

Funding: This research was funded by 43/17/RPZP Project of the Ministry of Health, grant No. P503/12/G147 of the Czech Science Foundation, GACR 18-02079S, and Progres Q25 and Q29 of the Charles University.

Acknowledgments: We would like to thank all subjects who volunteered in the study. 
Conflicts of Interest: The authors declare no conflict of interest.

\section{References}

1. Bello, D.; Wardle, B.L.; Ahn, K.; Yamamoto, N.; Garcia, E.; deVilloria, R.G.; Hart, A.J.; Ellenbecker, M.J.; Hallock, M. Exposure to nanoscale particles and fibers during machining of hybrid advanced composites containing carbon nanotubes. J. Nanopart. Res. 2009, 11, 231-249. [CrossRef]

2. Bello, D.; Wardle, B.L.; Zhang, J.; Yamamoto, N.; Santeufemio, C.; Hallock, M.; Virji, M.A. Characterization of exposures to nanoscale particles and fibers during drilling of hybrid advanced composites containing carbon nanotubes. Int. J. Occup. Environ. Health 2010, 16, 434-450. [CrossRef] [PubMed]

3. Boonruksa, P.; Bello, D.; Zhang, J.; Isaacs, J.A.; Mead, J.; Woskie, S. Characterization of potential exposures to nanoparticles and fibers during manufacturing and recycling of carbon nanotube reinforced polypropylene composites. Ann. Occup. Hyg. 2016, 60, 40-55. [CrossRef] [PubMed]

4. Boonruksa, P.; Bello, D.; Zhang, J.; Isaacs, J.A.; Mead, J.L.; Woskie, S.R. Exposures to nanoparticles and fibers during injection molding and recycling of carbon nanotube reinforced polycarbonate composites. J. Expo. Sci. Environ. Epidemiol. 2017, 27, 379-390. [CrossRef] [PubMed]

5. Liou, S.H.; Tsai, C.S.; Pelclova, D.; Schubauer-Berigan, M.K.; Schulte, P.A. Assessing the first wave of epidemiological studies of nanomaterial workers. J. Nanopart. Res. 2015, 17, 413. [CrossRef] [PubMed]

6. Schulte, P.A.; Iavicoli, I.; Rantanen, J.H.; Dahmann, D.; Iavicoli, S.; Pipke, R.; Guseva Canu, I.; Boccuni, F.; Ricci, M.; Polci, M.L.; et al. Assessing the protection of the nanomaterial workforce. Nanotoxicology 2016, 10, 1013-1019. [CrossRef] [PubMed]

7. Iavicoli, I.; Leso, V.; Schulte, P.A. Biomarkers of susceptibility. State of the art and implications for occupational exposure to engineered nanomaterials. Toxicol. Appl. Pharmacol. 2016, 299, 112-124. [CrossRef] [PubMed]

8. Guseva Canu, I.; Schulte, P.A.; Riediker, M.; Fatkhutdinova, L.; Bergamaschi, E. Methodological, political and legal issues in the assessment of the effects of nanotechnology on human health. J. Epidemiol. Community Health 2018, 72, 148-153. [CrossRef] [PubMed]

9. Chalbot, M.-C.; Pirela, S.V.; Schifman, L.; Kasaraneni, V.; Oyanedel-Craver, V.; Bello, D.; Castranova, V.; Qian, Y.; Thomas, T.; Kavouras, I.G.; et al. Synergistic effects of engineered nanoparticles and organics released from laser printers using nano-enabled toners: Potential health implications from exposures to the emitted organic aerosol. Environ. Sci. Nano 2017, 4, 2144-2156. [CrossRef]

10. Keane, M.; Stone, S.; Chen, B. Welding fumes from stainless steel gas metal arc processes contain multiple manganese chemical species. J. Environ. Monit. 2010, 12, 1133-1140. [CrossRef] [PubMed]

11. Valuntaite, V.; Girgždienè, R. Outdoor and indoor ozone level-A potential impact on human health. Vojnosanit. Pregl. 2015, 72, 696-701. [CrossRef] [PubMed]

12. Cena, L.G.; Chisholm, W.P.; Keane, M.J.; Chen, B.T. A field study on the respiratory deposition of the nano-sized fraction of mild and stainless steel welding fume metals. J. Occup. Environ. Hyg. 2015, 12, 721-728. [CrossRef] [PubMed]

13. Horváth, I.; Barnes, P.J.; Loukides, S.; Sterk, P.J.; Högman, M.; Olin, A.C.; Amann, A.; Antus, B.; Baraldi, E.; Bikov, A.; et al. A European respiratory society technical standard: Exhaled biomarkers in lung disease. Eur. Respir. J. 2017, 49, 1600965. [CrossRef] [PubMed]

14. Almstrand, A.C.; Bake, B.; Ljungström, E.; Larsson, P.; Bredberg, A.; Mirgorodskaya, E.; Olin, A.C. Effect of airway opening on production of exhaled particles. J. Appl. Physiol. 2010, 108, 584-588. [CrossRef] [PubMed]

15. Hsieh, S.F.; Bello, D.; Schmidt, D.F.; Pal, A.K.; Stella, A.; Isaacs, J.A.; Rogers, E.J. Mapping the biological oxidative damage of engineered nanomaterials. Small 2013, 9, 1853-1865. [CrossRef] [PubMed]

16. Manke, A.; Wang, L.; Rojanasakul, Y. Mechanisms of nanoparticle-induced oxidative stress and toxicity. Biomed. Res. Int. 2013, 2013, 942916. [CrossRef] [PubMed]

17. Khanna, P.; Ong, C.; Bay, B.H.; Bae, G.H. Nanotoxicity: An interplay of oxidative stress, inflammation and cell death. Nanomaterials 2015, 5, 1163-1180. [CrossRef] [PubMed]

18. Bello, D.; Warheit, D.B. Biokinetics of engineered nano- $\mathrm{TiO}_{2}$ in rats administered by different exposure routes: Implications for human health. Nanotoxicology 2017, 11, 431-433. [CrossRef] [PubMed]

19. Toyokuni, S. Molecular mechanisms of oxidative stress-induced carcinogenesis: From epidemiology to oxygenomics. IUBMB Life 2008, 60, 441-447. [CrossRef] [PubMed] 
20. Lee, J.F.; Tung, S.P.; Wang, D.; Yeh, D.Y.; Fong, Y.; Young, Y.C.; Leu, F.J. Lipoxygenase pathway mediates increases of airway resistance and lung inflation induced by exposure to nanotitanium dioxide in rats. Oxid. Med. Cell. Longev. 2014, 2014, 485604. [CrossRef] [PubMed]

21. Kuka, S.; Hurbankova, M.; Drlickova, M.; Baska, T.; Hudeckova, H.; Tatarkova, Z. Nanomaterials-A new and former public health issue. The case of Slovakia Cent. Eur. J. Public Health 2016, 24, 308-313. [CrossRef] [PubMed]

22. Donaldson, K.; Poland, C.A. Nanotoxicity: Challenging the myth of nano-specific toxicity. Curr. Opin. Biotechnol. 2013, 24, 724-734. [CrossRef] [PubMed]

23. Antus, B. Oxidative stress markers in sputum. Oxid. Med. Cell. Longev. 2016, 2016, 2930434. [CrossRef] [PubMed]

24. Pelclova, D.; Zdimal, V.; Komarc, M.; Schwarz, J.; Kostejn, M.; Dvorackova, S.; Ondracek, J.; Kacer, P.; Vlckova, S.; Fenclova, Z.; et al. Respiratory symptoms and markers of inflammation in nanocomposite production workers. Occup. Environ. Med.. submitted.

25. Berner, A.; Lürzer, C. Mass size distributions of traffic aerosols at Vienna. J. Phys. Chem. 1980, 84, $2079-2083$. [CrossRef]

26. Stefancova, L.; Schwarz, J.; Mäkelä, T.; Hillamo, R.; Smolik, J. Comprehensive characterization of original 10-stage and 7-stage modified Berner Type Impactors. Aerosol Sci. Technol. 2011, 45, 88-100. [CrossRef]

27. Talbot, N.; Kubelova, L.; Makes, O.; Ondracek, J.; Cusack, M.; Schwarz, J.; Vodicka, P.; Zikova, N.; Zdimal, V. Transformations of aerosol particles from an outdoor to indoor environment. Aerosol Air Qual. Res. 2017, 17, 653-665. [CrossRef]

28. Syslova, K.; Kacer, P.; Kuzma, M.; Klusackova, P.; Fenclova, Z.; Lebedova, J.; Pelclova, D. Determination of 8-iso-prostaglandin $\mathrm{F}(2 \alpha)$ in exhaled breath condensate using combination of immunoseparation and LC-ESI-MS/MS. J. Chromatogr. B 2008, 867, 8-14. [CrossRef] [PubMed]

29. Syslova, K.; Kacer, P.; Kuzma, M.; Pankracova, A.; Fenclova, Z.; Vlckova, S.; Lebedova, J.; Pelclova, D. LC-ESI-MS/MS method for oxidative stress multimarker screening in the exhaled breath condensate of asbestosis/silicosis patients. J. Breath Res. 2010, 4, 017104. [CrossRef] [PubMed]

30. Syslova, K.; Böhmova, A.; Mikoska, M.; Kuzma, M.; Pelclova, D.; Kacer, P. Multimarker screening of oxidative stress in aging. Oxid. Med. Cell. Longev. 2014, 2014, 562860. [CrossRef] [PubMed]

31. Klusackova, P.; Lebedova, J.; Kacer, P.; Kuzma, M.; Brabec, M.; Pelclova, D.; Fenclova, Z.; Navratil, T. Leukotrienes and 8-isoprostane in exhaled breath condensate in bronchoprovocation tests with occupational allergens. Prostaglandins Leukot. Essent. Fatty Acids 2008, 78, 281-292. [CrossRef] [PubMed]

32. Effros, R.M.; Biller, J.; Foss, B.; Hoagland, K.; Dunning, M.B.; Castillo, D.; Bosbous, M.; Sun, F.; Shaker, R. A simple method for estimating respiratory solute dilution in exhaled breath condensates. Am. J. Respir. Crit. Care Med. 2003, 168, 1500-1505. [CrossRef] [PubMed]

33. Wood, A.M.; Tan, S.L.; Stockley, R.A. Chronic obstructive pulmonary disease: Towards pharmacogenetics. Genome Med. 2009, 1, 112. [CrossRef] [PubMed]

34. Huang, Y.W.; Cambre, M.; Lee, H.J. The toxicity of nanoparticles depends on multiple molecular and physicochemical mechanisms. Int. J. Mol. Sci. 2017, 18, 2702. [CrossRef] [PubMed]

35. Runa, S.; Hussey, M.; Payne, C.K. Nanoparticle-Cell interactions: Relevance for public health. J. Phys. Chem. B 2018, 122, 1009-1016. [CrossRef] [PubMed]

36. Theriaulta, M.; Yoeutha, S.; Matara, J.; Martin, J.; Bello, D.; Barry, C. Investigation of nanoparticles emitted when injection molding neat and additive-filled polypropylene and polycarbonate. In Proceedings of the 32nd International Conference of the Polymer Processing Society, Lyon, France, 25-29 July 2016.

37. Malvindi, M.A.; De Matteis, V.; Galeone, A.; Brunetti, V.; Anyfantis, G.C.; Athanassiou, A.; Cingolani, R.; Pompa, P.P. Toxicity assessment of silica coated iron oxide nanoparticles and biocompatibility improvement by surface engineering. PLoS ONE 2014, 9, e85835. [CrossRef] [PubMed]

38. Pelclova, D.; Zdimal, V.; Fenclova, Z.; Vlckova, S.; Turci, F.; Corazzari, I.; Kacer, P.; Schwarz, J.; Zikova, N.; Makes, O.; et al. Markers of oxidative damage of nucleic acids and proteins among workers exposed to $\mathrm{TiO}_{2}$ (nano) particles. Occup. Environ. Med. 2016, 73, 110-118. [CrossRef] [PubMed]

39. Pelclova, D.; Zdimal, V.; Kacer, P.; Zikova, N.; Komarc, M.; Fenclova, Z.; Vlckova, S.; Schwarz, J.; Makes, O.; Syslova, K.; et al. Markers of lipid oxidative damage in the exhaled breath condensate of nanoTiO 2 production workers. Nanotoxicology 2017, 11, 52-63. [CrossRef] [PubMed] 
40. Pelclova, D.; Zdimal, V.; Kacer, P.; Fenclova, Z.; Vlckova, S.; Syslova, K.; Navratil, T.; Schwarz, J.; Zikova, N.; Barosova, H.; et al. Oxidative stress markers are elevated in exhaled breath condensate of workers exposed to nanoparticles during iron oxide pigment production. J. Breath Res. 2016, 10, 016004. [CrossRef] [PubMed]

41. Pelclova, D.; Zdimal, V.; Kacer, P.; Komarc, M.; Fenclova, Z.; Vlckova, S.; Zikova, N.; Schwarz, J.; Makes, O.; Navratil, T.; et al. Markers of lipid oxidative damage among office workers exposed intermittently to air pollutants including nanoTiO ${ }_{2}$ particles. Rev. Environ. Health 2017, 32, 193-200. [CrossRef] [PubMed]

42. Pelclova, D.; Zdimal, V.; Kacer, P.; Vlckova, S.; Fenclova, Z.; Navratil, T.; Komarc, M.; Schwarz, J.; Zikova, N.; Makes, O.; et al. Markers of nucleic acids and proteins oxidation among office workers exposed to air pollutants including (nano) $\mathrm{TiO}_{2}$ particles. Neuro Endocrinol. Lett. 2016, 37, 3-16. [PubMed]

43. Pelclova, D.; Barosova, H.; Kukutschova, J.; Zdimal, V.; Navratil, T.; Fenclova, Z.; Vlckova, S.; Schwarz, J.; Zikova, N.; Kacer, P.; et al. Raman microspectroscopy of exhaled breath condensate and urine in workers exposed to fine and nanoTiO 2 particles: A cross-sectional study. J. Breath Res. 2015, 9, 036008. [CrossRef] [PubMed]

44. Kwon, S.; Yang, Y.S.; Yang, H.S.; Lee, J.; Kang, M.S.; Lee, B.S.; Lee, K.; Song, C.W. Nasal and pulmonary toxicity of titanium dioxide nanoparticles in rats. Toxicol. Res. 2012, 28, 217-224. [CrossRef] [PubMed]

45. Martin, J.; Bello, D.; Bunker, K.; Shafer, M.; Christiani, D.; Woskie, S.; Demokritou, P. Occupational exposure to nanoparticles at commercial photocopy centers. J. Hazard. Mater. 2015, 298, 351-360. [CrossRef] [PubMed]

46. Khatri, M.; Bello, D.; Gaines, P.; Martin, J.; Pal, A.K.; Gore, R.; Woskie, S. Nanoparticles from photocopiers induce oxidative stress and upper respiratory tract inflammation in healthy volunteers. Nanotoxicology 2013, 7, 1014-1027. [CrossRef] [PubMed]

47. Lai, C.H.; Huang, H.B.; Chang, Y.C.; Su, T.Y.; Wang, Y.C.; Wang, G.C.; Chen, J.E.; Tang, C.S.; Wu, T.N.; Liou, S.H. Exposure to fine particulate matter causes oxidative and methylated DNA damage in young adults: A longitudinal study. Sci. Total Environ. 2017, 598, 289-296. [CrossRef] [PubMed]

48. Khatri, M.; Bello, D.; Martin, J.; Bello, A.; Gore, R.; Demokritou, P.; Gaines, P. Chronic upper airway inflammation and oxidative stress in photocopier operators: Mechanistic insights. NanoImpact 2017, 5, 133-145. [CrossRef]

49. Pirela, S.V.; Martin, J.; Bello, D.; Demokritou, P. Nanoparticle exposures from nano-enabled toner-based printing equipment and human health: State of science and future research needs. Crit. Rev. Toxicol. 2017, 47, 683-709. [CrossRef] [PubMed]

50. Liou, S.H.; Chen, Y.C.; Liao, H.Y.; Wang, C.J.; Chen, J.S.; Lee, H.L. Increased levels of oxidative stress biomarkers in metal oxides nanomaterial-handling workers. Biomarkers 2016, 21, 600-606. [CrossRef] [PubMed]

51. Liou, S.H.; Wu, W.T.; Liao, H.Y.; Chen, C.Y.; Tsai, C.Y.; Jung, W.T.; Lee, H.L. Global DNA methylation and oxidative stress biomarkers in workers exposed to metal oxide nanoparticles. J. Hazard. Mater. 2017, 331, 329-335. [CrossRef] [PubMed]

52. Zhao, L.; Zhu, Y.; Chen, Z.; Xu, H.; Zhou, J.; Tang, S.; Xu, Z.; Kong, F.; Li, X.; Zhang, Y.; et al. Cardiopulmonary effects induced by occupational exposure to titanium dioxide nanoparticles. Nanotoxicology 2018, 12, 169-184. [CrossRef] [PubMed]

53. Martin, J.; Demokritou, P.; Woskie, S.; Bello, D. Indoor air quality in photocopy centers, nanoparticle exposures at photocopy workstations, and the need for exposure controls. Ann. Work Expo. Health 2017, 61, 110-122. [CrossRef] [PubMed]

54. Pelclova, D.; Fenclova, Z.; Kacer, P.; Kuzma, M.; Navratil, T.; Lebedova, J. 8-isoprostane and leukotrienes in exhaled breath condensate in Czech subjects with silicosis. Ind. Health 2007, 45, 766-774. [CrossRef] [PubMed]

55. Pelclova, D.; Fenclova, Z.; Kacer, P.; Kuzma, M.; Navratil, T.; Lebedova, J. Increased 8-isoprostane, a marker of oxidative stress in exhaled breath condensate in subjects with asbestos exposure. Ind. Health 2008, 46, 484-489. [CrossRef] [PubMed]

56. Pelclova, D.; Fenclova, Z.; Syslova, K.; Vlckova, S.; Lebedova, J.; Pecha, O.; Belacek, J.; Navratil, T.; Kuzma, M.; Kacer, P. Oxidative stress markers in exhaled breath condensate in lung fibroses are not significantly affected by systemic diseases. Ind. Health 2011, 49, 746-754. [CrossRef] [PubMed]

(C) 2018 by the authors. Licensee MDPI, Basel, Switzerland. This article is an open access article distributed under the terms and conditions of the Creative Commons Attribution (CC BY) license (http:/ / creativecommons.org/licenses/by/4.0/). 